\title{
A cladistic analysis of the genera of Macrothricidae Norman \& Brady (Crustacea, Cladocera, Radopoda)
}

\author{
Lourdes M. A. Elmoor-Loureiro
}

Laboratório de Zoologia, Universidade Católica de Brasília. QS 7 lote 1, Bloco M, sala 331, 71966-700 Taguatinga, Distrito Federal, Brasil.E-mail: lourdes@ucb.br

\begin{abstract}
A cladistic analysis of the genera of the Macrothricidae (Crustacea, Cladocera, Radopoda) was performed based on 36 morphological characters, and including 15 terminal taxa (three as outgroups). The single tree obtained from this analysis supported the monophyly of Macrothricidae and Macrothricinae. The group called as "non-Macrothricinae" was indicated as paraphyletic. Neothricidae was also not supported.

KEY WORDS. Anomopoda, Macrothricinae, Macrothricoidea, phylogeny.
\end{abstract}

RESUMO. Análise cladística dos gêneros de Macrothticidae Norman \& Brady (Crustacea, Cladocera, Radopoda). Foi conduzida uma análise cladística dos gêneros sul-americanos de Macrothricidae (Crustacea, Cladocera, Radopoda) com base em 36 caracteres morfológicos e incluindo 15 taxa terminais (três como grupos externos). Uma única árvore foi obtida pela análise, a qual suporta o monofiletismo de Macrothricidae e de Macrothricinae. O grupo chamado de "não-Macrothricinae" é indicado como parafilético. Neothricidae também não encontrou suporte.

PALAVRAS CHAVE. Anomopoda, filogenia, Macrothricinae, Macrothricoidea.

In its original definition, the family Macrothricidae Norman \& Brady, 1867 (Branchiopoda, Anomopoda) embraced all littoral cladoceran genera with antennules long and attached near the tip of head, without rostrum, antenna with three endopodite and four expedite segments, and postabdomen with strong and numerous marginal dentils (for a detailed description, see Alonso 1996). According to Fryer $(1974,1995)$, most of the primitive anomopod characteristics were retained in this family.

In the last decade, Macrothricidae was redefined. At first, SMIRNov (1992) transferred the genus Ilyocryptus Sars, 1892 to a new family, and more recently Dumont \& Silva-Briano (1998) elevated the remaining group to superfamily status (Macrothricoidea). The Macrothricoidea embraces the families Macrothricidae strictu sensu, Acantholeberidae Smirnov, 1976, Neothricidae Dumont \& Silva-Briano, 1997, and Ophryoxidae Smirnov, 1976. According to Dumont \& Silva-Briano (1998), the Macrothricidae strictu sensu includes 11 genera, characterized by fork setae on trunk limb I and reduction of the number of trunk limb setae, if compared with more "primitive" macrothricid-like families. For example, the Acantholeberidae possess 8, 8, and 7 setae on exopodites of the trunk limbs III, IV, and V respectively, while the Macrothricidae have the maximum of 6, 6, and 3 setae on the same exopodites.

Although Dumont \& Silva-Briano (1998) suggested a hypothetical evolutionary tree for the families of Macrothricoidea (and other Radopoda Dumont \& Silva-Briano, 1997), the phy- logenetic relationships within the Macrothricoidea have not yet been submitted to a cladistic analysis. As a starting point, the present study aims to investigate the phylogenetic relationships among the genera of the Family Macrothricidae, based on a formal cladistic analysis of 36 morphological characters.

\section{MATERIAL AND METHODS}

The ingroup taxa set consisted of 12 species representing the genera of Macrothricidae. The genus Cactus Vávra, 1900 was not included in the analysis because only a single specimen is known and its description is very vague. Three species of Macrothrix Baird, 1843 were included in the analysis in order to represent the synonymous genera Iheringula Sars, 1900 and Echinisca Liévin,1848. Streblocerus Sars, 1862 was represented by two terminal taxa because differences among species were observed. As outgroup, three genera of Macrothricoidea were included: two considered as "primitive" (Acantholeberis Lilljeborg,1846 and Ophryoxus Sars, 1862) and one considered as advanced (Neothrix Gurney, 1927) (Dumont \& Silva-Briano 1998). The list of terminal taxa, the material examined, and the literature source are presented in table I.

The 36 selected morphological characters and the character states are summarized in table II. Most of these characters is traditionally used in cladoceran taxonomy and is well described in Alonso (1996) and Dumont \& Negrea (2002). The 
Table I. List of terminal taxa, localities from which specimens were examined in present study (all localities in Brazil), and literature sources.

\begin{tabular}{|c|c|c|}
\hline & Species & Localities or literature source \\
\hline \multirow[t]{3}{*}{ Outgroup } & Acantholeberis curvirostris (Müller, 1776) & Fryer (1974), Dumont \& Silva-Briano (1998) \\
\hline & Neothrix armata Gurney, 1927 & SMIRNov (1992), DUMONt \& Silva-Briano (1998) \\
\hline & Ophryoxus gracilis Sars, 1862 & Smirnov (1992), Dumont \& Silva-Briano (1998) \\
\hline \multirow[t]{16}{*}{ Ingroup } & Bunops tuberculata (Fryer \& Paggi, 1972) & Fryer \& PaGgi (1972), Silva-Briano \& Dumont (2001) \\
\hline & Drepanothrix dentata (Eurén, 1861) & SMirnov (1992), Dumont \& Silva-Briano (1998) \\
\hline & Grimaldina brazzai Richard, 1892 & Bahia $\left(12^{\circ} 34^{\prime} 40.9^{\prime \prime} \mathrm{S}, 38^{\circ} 00^{\prime} 47.4^{\prime \prime W}\right)$ \\
\hline & Guernella raphaelis Richard, 1892 & PaGgi (1976), Fryer (1974), Dumont \& Silva-Briano (1998) \\
\hline & Lathonura rectirostris (O.F. Muller, 1785) & SMIRNov (1992), DUMONt \& Silva-Briano (1998) \\
\hline & Macrothrix elegans Sars, 1901 & Bahia $\left(12^{\circ} 35^{\prime} 43.0^{\prime \prime} \mathrm{S}, 39^{\circ} 00^{\prime} 22.9^{\prime \prime} \mathrm{W}\right)$ \\
\hline & & Distrito Federal $\left(15^{\circ} 50^{\prime} 29.7^{\prime \prime S}, 47^{\circ} 53^{\prime} 55.1\right.$ "W) \\
\hline & Macrothrix laticornis group & Goiás (14²7'42.9"S, 4700'15.2"W) \\
\hline & Macrothrix paulensis (Sars, 1888) & Distrito Federal $\left(15^{\circ} 41^{\prime} 16.5^{\prime \prime S}, 47^{\circ} 56^{\prime} 22.2^{\prime \prime W}\right)$ \\
\hline & & Bahia $\left(12^{\circ} 45^{\prime} 42.2^{\prime \prime} \mathrm{S}, 38^{\circ} 10^{\prime} 07.7 \mathrm{~W}\right)$ \\
\hline & Paraphryoxus tubulatus Doolittle, 1909 & SMIRNov (1992), DUMONt \& SiLVA-BRIANo (1998) \\
\hline & Pseudomoina lemnae (King, 1853) & Petkovski (1973), Dumont \& Silva-Briano (1998) \\
\hline & Streblocerus pygmaeus Sars, 1901 & Distrito Federal $\left(15^{\circ} 41^{\prime} 16.5^{\prime \prime S}, 47^{\circ} 56^{\prime} 22.2 \mathrm{~W}\right)$ \\
\hline & & Goiás (1509'15.8"S, 47²8'04.7"W) \\
\hline & Streblocerus serricaudatus (Fischer, 1847) & Fryer (1974), Dumont \& Silva-Briano (1998) \\
\hline & Wlassicsia pannonica Daday, 1904 & Smirnov (1992), Dumont \& Silva-Briano (1998) \\
\hline
\end{tabular}

terminology used to describe the trunk limbs follows Dumont \& Silva-Briano (1998) and Dumont \& Negrea (2002). The abbreviation TL $i$ is used to indicate the trunk limbs I to $\mathrm{V}$, and endite $i$ - TL $i$ to indicate the endite 1 to 4 of the corresponding trunk limb. When samples were available, the character states were confirmed by direct observation of the specimens. Character 23 followed Fryer (1974). Some discrepancies were detected among Guernella Richard,1892 data from Fryer (1974), PAGGI (1976), and Dumont \& Silva-Briano (1998), so in characters 10 , 16,20 , and 27 the option was for the description of South American specimens (PAGGI 1976). The data matrix is presented in the table III.

Parsimony analysis was performed with PAUP 4 (SwOFFord 1999), using the exhaustive search option. All characters were considered unordered and unweighted. ACCTRAN optimization was used and the tree was rooted using the outgroup method. The distribution of the characters states was further investigated using MacClade 3.04 (MADDISON \& MADDISON 1992).

\section{RESULTS AND DISCUSSION}

The analysis produced a single most parsimonious tree $(l$ = 79 steps; $\mathrm{CI}=0.5696 ; \mathrm{RI}=0.6991 ; \mathrm{RCI}=0.3982)$, shown in figure 1 . The apomorphy list is presented in table IV.

The monophyly of Macrothricidae is supported by 9 characters (Tab. IV). The presence of five pairs of trunk limbs, TL I without seta at exopodite base, TL II with duplication setae re-

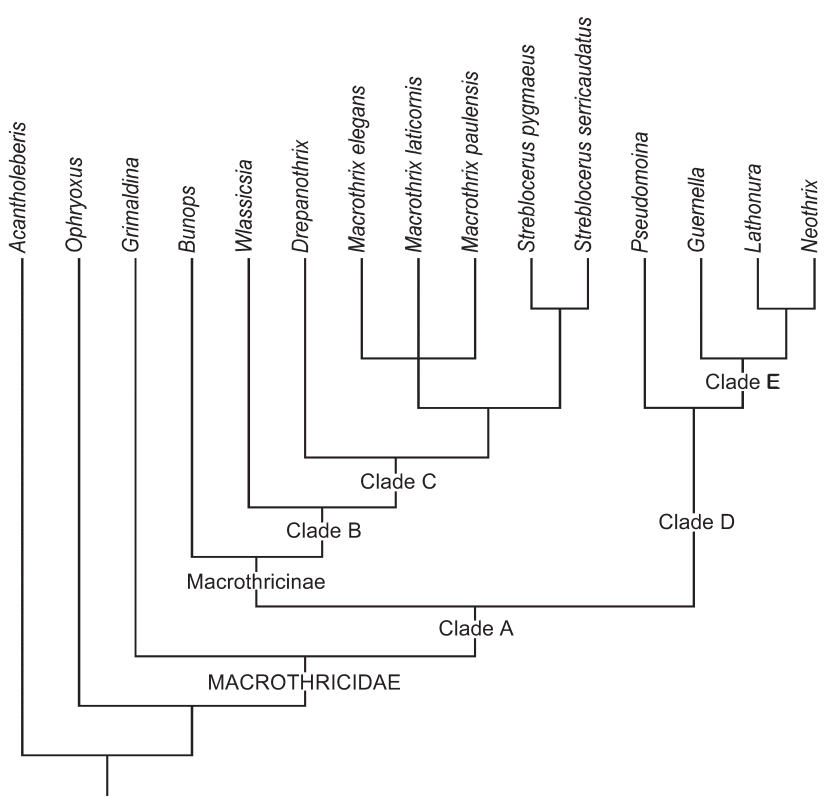

Figure 1. Phylogenetic topology for the genera of Macrothricidae. Single tree of minimum length $(I=79$ steps; $\mathrm{Cl}=0.5696$; $\mathrm{RI}=$ $0.6991 ; \mathrm{RCl}=0.3982$ ).

duced and modified (Fig. 2), TL IV without pre-epipodite, and TL $V$ with 1 or 2 setae on exopodite are constant characters within 
Table II. List of characters and character states.

\begin{tabular}{|c|c|c|}
\hline Number & Character & State \\
\hline 1 & Antennule, curved outward: & (0) absent; (1) present \\
\hline 2 & Antennule, thick and flat: & (0) absent; (1) present \\
\hline 3 & Antenna, seta on second exopodite segment: & (0) absent; (1) present \\
\hline 4 & Antenna, seta on third exopodite segment: & (0) absent; (1) present \\
\hline 5 & Number of trunk limbs: & (0) 6 ; (1) 5 \\
\hline 6 & Trunk limb I, ejector hooks: & (0) $2 ;(1) 1 ;(2)$ none \\
\hline 7 & Trunk limb I, plumose setae on the first endite: & (0) $4 ;(1) 3 ;(2) 2$ \\
\hline 8 & Trunk limb I, fork-like seta: & (0) absent; (1) present \\
\hline 9 & Trunk limb I, fork-like seta on endite 1 : & (0) absent; (1) present \\
\hline 10 & Trunk limb I, fork-like seta on endite 2 : & (0) absent; (1) present \\
\hline 11 & Trunk limb I, setae on endite 3 sclerotized: & (0) absent; (1) present \\
\hline 12 & Trunk limb I, scrapers on endite 3 : & (0) absent; (1) present \\
\hline 13 & Trunk limb I, distalmost seta on endite 3 apart from the others: & (0) absent; (1) present \\
\hline 14 & Trunk limb I, setae on IDL: & (0) $3 ;(1) 4$ \\
\hline 15 & Trunk limb I, setae on exopodite (ODL): & (0) $2 ;(1) 1$ \\
\hline 16 & Trunk limb I, seta at exopodite (ODL) base: & (0) present; (1) absent \\
\hline 17 & Trunk limb I, gnathobasic setae: & (0) 2 or more; (1) 1 or none \\
\hline 18 & Trunk limb II, number of scrapers: & (0) 8 ; (1) 7 ; (2) 9 \\
\hline 19 & Trunk limb II, duplication of the row of scrapers * & (0) present; (1) absent \\
\hline 20 & Trunk limb II, duplication of the row of scrapers & (0) plumose setae; (1) reduced and modified \\
\hline 21 & Trunk limb II, setae on exopodite & (0) $2-3$; (1) 1 ; (2) none \\
\hline 22 & Trunk limb II, gnathobasic filter comb & (0) 8 or more; (1) 6 or $7 ;$ (2) 4 or 5 \\
\hline 23 & Trunk limb III, setae on endite external lobe ** & (0) filtratory; (1) not filtratory \\
\hline 24 & Trunk limb III, distal seta modified as a thick spine: & (0) absent; (1) present \\
\hline 25 & Trunk limb III, gnathobasic filter comb setae: & (0) 6 or $7 ;(1) 8$ or more; (2) none \\
\hline 26 & Trunk limb III, setae on exopodite: & (0) 8 or more; (1) 5 or 6 ; (2) 4 or 3 \\
\hline 27 & Trunk limb IV, pre-epipodite: & (0) present; (1) absent \\
\hline 28 & Trunk limb IV, setae of the internal series: & (0) present; (1) absent \\
\hline 29 & Trunk limb IV, setae on gnathobasic filter comb: & (0) 8 or more; (1) 6 or 5 ; (2) 2 or less \\
\hline 30 & Trunk limb IV, setae on exopodite: & (0) 8 or more; (1) 4 to 6 ; (2) 2 or 3 \\
\hline 31 & Trunk limb V, setae on exopodite: & (0) 6 or $7 ;(2) 1$ or 2 \\
\hline 32 & Postabdomen, marginal denticles in transversal rows: & (0) absent; (1) present \\
\hline 33 & Postabdomen bilaterally compressed, with a plate-like dorsal expansion: & (0) absent; (1) present \\
\hline 34 & Postabdomen, postanal expansion: & (0) absent; (1) present \\
\hline 35 & Terminal claw & (0) long and slender; ( 1 ) short and robust \\
\hline 36 & Gut coiling: & (0) not coiled; (1) coiled \\
\hline
\end{tabular}

* The duplication is considered present even if only sensillum occurs; ${ }^{* *}$ According Fryer (1976 - Tab. I)

the family, but the other apomorphic characters (4, 22, 29, and 30) have their states changed in more advanced clades.

Within the Macrothricidae, Grimaldina Richard, 1892 is the most basal genus and the sister group to a clade compounded by the remaining genera (Clade $\mathrm{A}$ in figure 1 ), which is supported by characters 17 (TL I with one seta on gnathobase or none) and 21 (TL II with 1 seta on exopodite). The reduction of the number of the TL I gnathobasic setae in more advanced clades also occurs in the Eurycercoidea (Eurycercidae have 3, while the Chydoridae have 0-2 setae). The present tree topology (Fig. 1), showing the non-Macrothricinae genera as paraphyletic, is in agreement with the supposition of DUMONT \& SILVA-BRIANO (1998) 
Table III. Data matrix, with 12 ingroup (Macrothricidae species) and 3 outgroup taxa $\left(^{*}\right) .(-)$ Indicates where the character is inapplicable.

$\begin{array}{llllllllllllllllllllllllllll}1 & 1 & 1 & 1 & 1 & 1 & 1 & 1 & 1 & 1 & 2 & 2 & 2 & 2 & 2 & 2 & 2 & 2 & 2 & 2 & 3 & 3 & 3 & 3 & 3 & 3 & 3\end{array}$ $\begin{array}{lllllllllllllllllllllllllllllllllllllllll}1 & 2 & 3 & 4 & 5 & 6 & 7 & 8 & 9 & 0 & 1 & 2 & 3 & 4 & 5 & 6 & 7 & 8 & 9 & 0 & 1 & 2 & 3 & 4 & 5 & 6 & 7 & 8 & 9 & 0 & 1 & 2 & 3 & 4 & 5 & 6\end{array}$

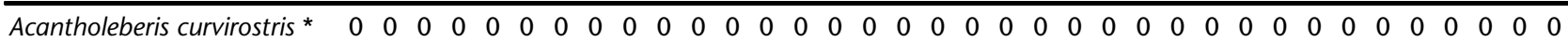

Neothrix armata * $\begin{array}{cccccccccccccccccccccccccccccccccccc}0 & 0 & 0 & 0 & 1 & 2 & 0 & 0 & 0 & 0 & 0 & 0 & 0 & 1 & 1 & 1 & 1 & 2 & 1 & 1 & 2 & 2 & 1 & 0 & 2 & 2 & 1 & 1 & 2 & 2 & 1 & 0 & 0 & 0 & - & 0\end{array}$

Ophryoxus gracilis * $\begin{array}{llllllllllllllllllllllllllllllllllll}0 & 0 & 0 & 0 & 0 & 0 & 1 & 0 & 0 & 0 & 0 & 0 & 0 & 0 & 0 & 0 & 0 & 0 & 0 & 0 & 2 & 0 & 0 & 0 & 0 & 0 & 0 & 0 & 0 & 0 & 0 & 0 & 0 & 0 & 0 & 1\end{array}$

Bunops tuberculata $\begin{array}{lllllllllllllllllllllllllllllllllllll}0 & 0 & 0 & 0 & 1 & 0 & 0 & 1 & 1 & 0 & 0 & 0 & 0 & 0 & 0 & 1 & 1 & 0 & 0 & 1 & 1 & 2 & 0 & 0 & 0 & 1 & 1 & 0 & 1 & 1 & 1 & 1 & 0 & 0 & 0 & 0\end{array}$

Drepanothrix dentata $\begin{array}{llllllllllllllllllllllllllllllllllll}0 & 0 & 0 & 0 & 1 & 0 & 0 & 1 & 1 & 1 & 0 & 0 & 0 & 0 & 1 & 1 & 1 & 0 & 0 & 1 & 0 & 1 & 1 & 1 & 2 & 1 & 1 & 0 & 2 & 2 & 1 & 1 & 0 & 0 & 0 & 0\end{array}$

Grimaldina brazzai $\begin{array}{llllllllllllllllllllllllllllllllllll}0 & 0 & 0 & 1 & 1 & 0 & 0 & 0 & 0 & 0 & 0 & 0 & 0 & 0 & 1 & 1 & 0 & 0 & 0 & 1 & 2 & 1 & 0 & 0 & 0 & 2 & 1 & 0 & 1 & 1 & 1 & 0 & 1 & 0 & 0 & 0\end{array}$

Guernella raphaelis $\begin{array}{llllllllllllllllllllllllllllllllllll}0 & 1 & 1 & 1 & 1 & 0 & 0 & 0 & 0 & 0 & 0 & 0 & 0 & 0 & 1 & 1 & 1 & 1 & 0 & 1 & 1 & 1 & 1 & 0 & 1 & 1 & 1 & 1 & 2 & 1 & 1 & 0 & 0 & 0 & 1 & 0\end{array}$

Lathonura rectirostris $\begin{array}{llllllllllllllllllllllllllllllllllll}0 & 0 & 1 & 1 & 1 & 0 & 0 & 0 & 0 & 0 & 0 & 0 & 0 & 1 & 0 & 1 & 1 & 0 & 0 & 1 & 1 & 1 & 1 & 1 & 2 & 2 & 1 & 1 & 2 & 2 & 1 & 0 & 0 & 0 & 1 & 0\end{array}$

Macrothrix elegans $\begin{array}{llllllllllllllllllllllllllllllllllll}0 & 0 & 0 & 1 & 1 & 0 & 2 & 1 & 1 & 1 & 1 & 0 & 1 & 0 & 0 & 1 & 1 & 0 & 1 & - & 1 & 2 & 1 & 1 & 2 & 2 & 1 & 0 & 2 & 2 & 1 & 1 & 0 & 0 & 1 & 0\end{array}$

Macrothrix laticornis $\begin{array}{lllllllllllllllllllllllllllllllllllll}0 & 0 & 0 & 1 & 1 & 0 & 2 & 1 & 1 & 1 & 1 & 0 & 1 & 0 & 0 & 1 & 1 & 0 & 0 & 1 & 1 & 2 & 1 & 1 & 2 & 2 & 1 & 0 & 2 & 2 & 1 & 1 & 0 & 0 & 1 & 0\end{array}$

Macrothrix paulensis $\begin{array}{llllllllllllllllllllllllllllllllllll}0 & 0 & 0 & 1 & 1 & 1 & 2 & 1 & 1 & 1 & 1 & 0 & 1 & 0 & 0 & 1 & 1 & 0 & 0 & 1 & 1 & 2 & 1 & 1 & 2 & 2 & 1 & 0 & 2 & 2 & 1 & 1 & 0 & 0 & 1 & 0\end{array}$

Pseudomoina lemnae $\begin{array}{llllllllllllllllllllllllllllllllllll}0 & 0 & 1 & 1 & 1 & 0 & 0 & 0 & 0 & 0 & 0 & 0 & 0 & 1 & 1 & 1 & 1 & 0 & 1 & - & 0 & 1 & 0 & 0 & 1 & 1 & 1 & 1 & 1 & 1 & 1 & 0 & 0 & 1 & 0 & 0\end{array}$

Streblocerus pygmaeus

$\begin{array}{llllllllllllllllllllllllllllllllllll}1 & 0 & 0 & 1 & 1 & 0 & 1 & 1 & 0 & 1 & 1 & 1 & 0 & 0 & 1 & 1 & 1 & 0 & 1 & - & 1 & 2 & 1 & 1 & 2 & 2 & 1 & 1 & 2 & 2 & 1 & 1 & 0 & 0 & 1 & 1\end{array}$

Streblocerus serricaudatus

Wlassicsia pannonica $\begin{array}{llllllllllllllllllllllllllllllllllll}0 & 0 & 0 & 1 & 1 & 0 & 1 & 1 & 1 & 1 & 0 & 0 & 0 & 0 & 0 & 1 & 1 & 0 & 0 & 1 & 1 & 2 & 1 & 1 & 0 & 1 & 1 & 0 & 1 & 1 & 1 & 1 & 0 & 0 & 1 & 0\end{array}$

and Dumont \& Negrea (2002), who did not consider the nonMacrothricinae genera as a formal subfamily.

Two main clades could be recognized within Clade A (Fig. 1): the Macrothricinae and the Clade D (consists of the nonmacrothricinae genera but Grimaldina). The Subfamily Macrothricinae (sensu Dumont \& Silva-Briano, 1998) is supported by four synapomorphies: the presence of fork-like setae on TL I (Fig. 3), their occurrence on endite 1 (lost in Streblocerus pygmaeus, but not in Streblocerus serricaudatus), TL II with 5 or 4 gnathobasic filter comb setae, and the arrangement of the postabdominal marginal denticles in transversal rows (characters $8,9,22$, and 32 ).

Within the Macrothricinae, Bunops Birge,1893 appears as the most basal genus (Fig. 1). Its sister group (Wlassicsia (Drepanothrix (Macrothrix + Streblocerus))), named as Clade B, is supported by three characters $(10,23$, and 24$)$. Of these, the presence of a fork-like seta on endite 2 of TL I have no parallel in other clades.

Macrothrix and Streblocerus are sister groups. The closest relationship between Macrothrix and Streblocerus, which was also found by OLEsEn $(1998,2000)$, is supported here by the sclerotized setae on endite 3-TL I and TL III with 3 or 4 setae on exopodite non filtratory setae on endite. Despite the differences observed among species, Streblocerus is well defined by the antennules curved outward, presence of scrapers on endite 3-TL I, and gut coiled (characters 1, 12 and 36). The monophyly of the genus Macrothrix is supported by the position of the distalmost seta endite 3-TL I, which is located apart from the others (character 13, Fig. 3). The present result suggests the maintenance of the synonymy of Macrothrix with Iheringula and Echinisca, but an analysis of the group including more terminal taxa is necessary to clarify this question.

The clade D (Pseudomoina (Guernella (Lathonura + Neothrix) is supported by presence of a seta on the second segment of antennal exopodite, TL III with 8 or more gnathobasic filter comb setae, and TL IV without internal series of setae (characters 3, 25 , and 28). The close relationship between Guernella and Pseudomoina Sars 1912 was previously suggested by FrYer (1974), but here Guernella appears closer to (Lathonura + Neothrix).

According to the present analysis, Neothrix is a very derived genus of Macrothricidae, and its phylogenetic position (Fig. 1) conflicts with the proposition that it represents a separate family (Dumont \& Silva-Briano 1998).

The present study has some limitations, beginning with the fact that information for many genera were collected from literature sources, that made the comparison difficult and limited the inclusion of more characters in data matrix. In addition, the characters used were limited by the optic microscopy resolution, which prevented the exploitation of the sensilar and glandular structures of the trunk limbs, as proposed by Dumont \& Silva-Briano (1997).

Despite these limitations, the present analysis represents an advance for the comprehension of the relationships within the Macrothricidae. Moreover, not supporting the Neothricidae and suggesting the paraphyly of the non-Macrothricinae genera, this paper argues for the revision of the current classification (cf. Dumont \& Negrea 2002). 
Table IV. Apomorphy list for the family Macrothricidae. The list shows the unambiguous character support for each clade, excluding the autapomorphy at species level.

\begin{tabular}{|c|c|c|}
\hline Clade & Character & \\
\hline \multirow[t]{9}{*}{ Macrothricidae } & $4(0 \rightarrow 1)^{\star}$ & Antenna, seta on third exopodite segment present \\
\hline & $5(0 \rightarrow 1)$ & Five pairs of trunk limbs \\
\hline & $16(0 \rightarrow 1)$ & TL I without seta at exopodite (ODL) base \\
\hline & $20(0 \rightarrow 1)$ & TL II with duplication setae reduced and modified \\
\hline & $22(0 \rightarrow 1)^{*}$ & TL II with 6 or 7 gnathobasic FC setae \\
\hline & $27(0 \rightarrow 1)$ & TL IV without pre-epipodite \\
\hline & $29(0 \rightarrow 1)^{*}$ & TL IV with 5 or 6 gnathobasic FC setae \\
\hline & $30(0 \rightarrow 1)^{*}$ & TL IV with 4 to 6 setae on exopodite \\
\hline & $31(0 \rightarrow 1)$ & TL $V$ with 1 or 2 setae on exopodite \\
\hline Grimaldina & $33(0 \rightarrow 1)$ & Postabdomen with a plate-like dorsal expansion \\
\hline \multirow[t]{2}{*}{ Clade A } & $17(0 \rightarrow 1)$ & TL I with 1 FC seta or none \\
\hline & $21(2 \rightarrow 1)$ & TL II with 1 seta on exopodite \\
\hline \multirow[t]{4}{*}{ Macrothricinae } & $8(0 \rightarrow 1)$ & TL I with fork-like setae \\
\hline & $9(0 \rightarrow 1)^{*}$ & TL I with fork-like seta on endite 1 \\
\hline & $22(1 \rightarrow 2) \#$ & TL II with 4 or 5 gnathobasic FC setae \\
\hline & $32(0 \rightarrow 1)$ & Postabdomen, transversal rows of marginal denticles \\
\hline Bunops & $4(1 \rightarrow 0) \#$ & Antenna, seta on third exopodite segment absent \\
\hline \multirow[t]{3}{*}{ Clade B } & $10(0 \rightarrow 1)$ & TL I with fork-like seta on endite 2 \\
\hline & $23(0 \rightarrow 1) \#$ & TL III with non filtratory setae on endite external lobe \\
\hline & $24(0 \rightarrow 1) \#$ & TL III with distal seta modified as a thick spine \\
\hline \multirow[t]{3}{*}{ Drepanothrix Sars 1862} & $4(1 \rightarrow 0) \#$ & Antenna, seta on third exopodite segment absent \\
\hline & $21(1 \rightarrow 0) \#$ & TL II with 2 or 3 seta on exopodite \\
\hline & $22(2 \rightarrow 1)$ & TL II with 6 or 7 gnathobasic FC setae \\
\hline \multirow[t]{3}{*}{ Clade C } & $25(0 \rightarrow 2)$ & TL III without gnathobasic FC setae \\
\hline & $29(1 \rightarrow 2) \#$ & TL IV with 2 or less gnathobasic FC setae \\
\hline & $30(1 \rightarrow 2)$ & TL IV with 2 to 3 setae on exopodite \\
\hline \multirow[t]{2}{*}{ Macrothrix + Streblocerus } & $11(0 \rightarrow 1)$ & Trunk limb I with sclerotized setae on endite 3 \\
\hline & $26(1 \rightarrow 2) \#$ & TL III with 3 or 4 setae on exopodite \\
\hline Macrothrix & $13(0 \rightarrow 1)$ & TL I with distalmost seta on endite 3 apart from the others \\
\hline \multirow[t]{3}{*}{ Streblocerus } & $1(0 \rightarrow 1)$ & Antennules curved outward \\
\hline & $12(0 \rightarrow 1)$ & TL I with scrapers on endite 3 \\
\hline & $36(0 \rightarrow 1)$ & Gut coiled \\
\hline \multirow[t]{3}{*}{ Clade D } & $3(0 \rightarrow 1)$ & Antenna with seta on second exopodite segment \\
\hline & $25(1 \rightarrow 0)^{*}$ & TL III with 8 or more gnathobasic FC setae \\
\hline & $28(0 \rightarrow 1) \#$ & TL IV without internal series of setae \\
\hline \multirow[t]{3}{*}{ Pseudomoina } & $19(0 \rightarrow 1) \#$ & TL II without duplication of the row of scrapers \\
\hline & $21(1 \rightarrow 0) \#$ & TL II with 2 or 3 seta on exopodite \\
\hline & $34(0 \rightarrow 1)$ & Postabdomen with a postanal expansion \\
\hline \multirow[t]{3}{*}{ Clade E } & $23(0 \rightarrow 1) \#$ & TL III with non filtratory setae on endite external lobe \\
\hline & $29(1 \rightarrow 2) \#$ & TL IV with 2 or less gnathobasic FC setae \\
\hline & $35(0 \rightarrow 1) \#$ & Terminal claw short and robust \\
\hline \multirow[t]{2}{*}{ Guernella } & $2(0 \rightarrow 1)$ & Antennules thick and flat \\
\hline & $18(0 \rightarrow 1)$ & TL II with 7 scrapers \\
\hline
\end{tabular}


Table IV. Continued.

\begin{tabular}{ccl}
\hline Clade & Character & \\
\hline Lathonura + Neothrix & $25(1 \rightarrow 2)$ & TL III without gnathobasic FC setae \\
& $26(1 \rightarrow 2) \#$ & TL III with 3 or 4 setae on exopodite \\
Lathonura Lilljeborg, 1853 & $30(1 \rightarrow 2)$ & TL IV with 2 or 3 setae on exopodite \\
Neothrix & $15(1 \rightarrow 0)$ & TL I with 2 setae on exopodite \\
& $24(0 \rightarrow 1) \#$ & TL III with distal seta modified as a thick spine \\
& $3(1 \rightarrow 0)$ & Antenna, seta on second exopodite segment absent \\
& $4(1 \rightarrow 0) \#$ & Antenna, seta on third exopodite segment absent \\
& $6(0 \rightarrow 2)$ & TL I without ejector hooks \\
& $18(0 \rightarrow 2)$ & TL II with 9 scrapers \\
& $21(1 \rightarrow 1) \#$ & TL II without duplication of the row of scrapers \\
& $22(1 \rightarrow 2)$ & TL II without seta on exopodite \\
\hline
\end{tabular}

$\left({ }^{*}\right)$ character state changed in more advanced clade, (\#) parallel in one or more taxa, (TL) trunk limb, (FC) gnathobasic filter comb.
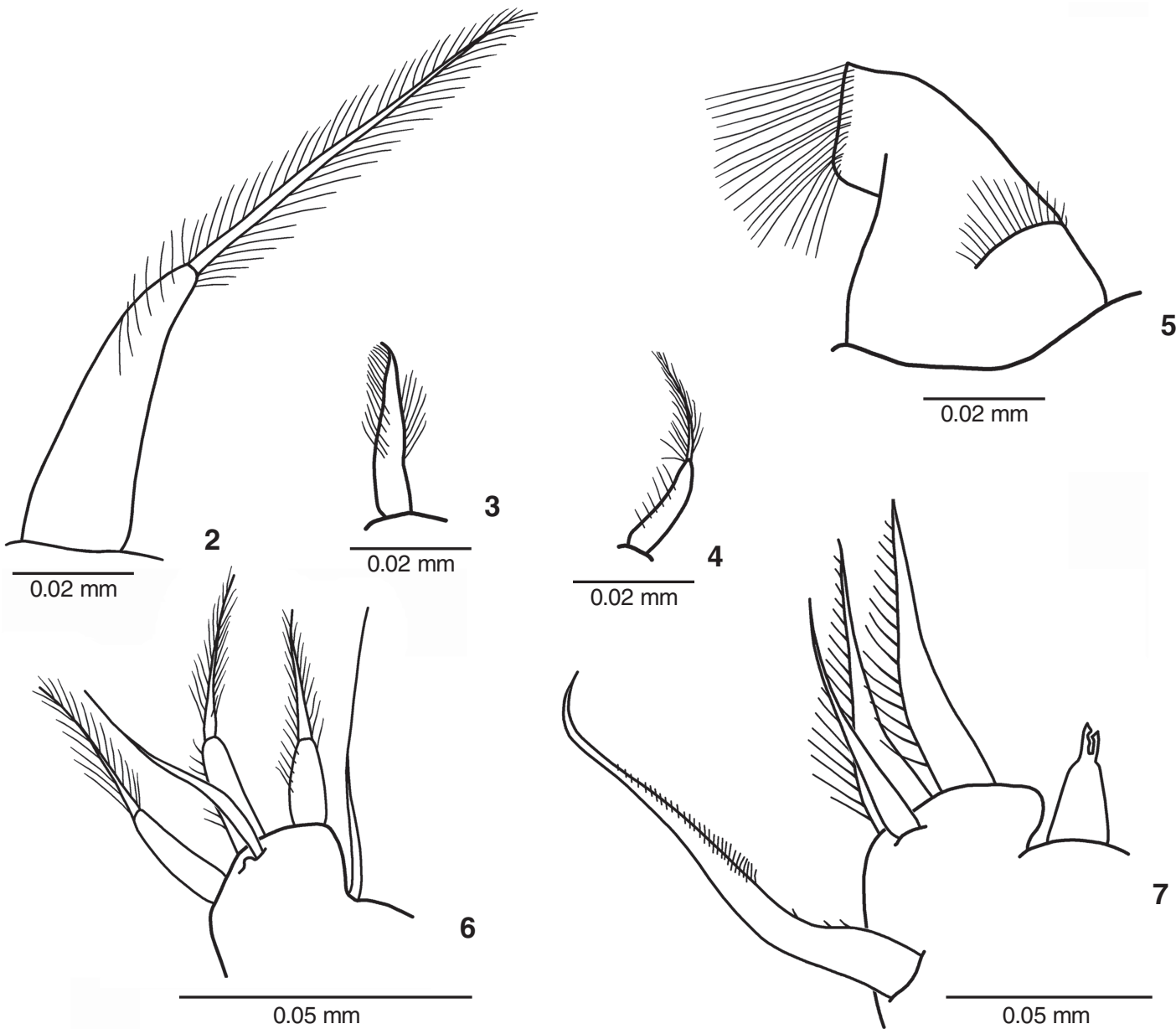

Figures 2-7. (2-5) Duplication of the row of scrapers on trunk limb II (character 21): (2) plumose setae (plesiomorphic state); (3-5) reduced and modified setae: (4) Grimaldina brazzai; (5) Macrothrix paulensis; (6-7) endite 3 of the trunk limb I and the position of the distal seta (character 16): (6) Grimaldina brazzai, representing the distal seta close to the others (plesiomorphic state); (7) Macrothrix paulensis, showing the distal seta apart from the others (apomorphic state). (ds) Distal seta, (e2) endite 2, (e3) endite 3, (fs) fork-like seta. 


\section{ACKNOWLEDGEMENTS}

I am very grateful to Dr. Reginaldo Constantino (Zoology Department, Universidade de Brasilia) for his advice on the cladistic analysis. I also thank Dr. Guarino G. Colli (Zoology Department, Universidade de Brasilia) and Ms. Vania Danigno for revising the English version of this manuscript. Thanks are also due to the Programa de Qualificação Docente of the Universidade Católica de Brasília for the financial support to the present study.

\section{REFERENCES}

Alonso, M. 1996. Branchiopoda. Madrid, Museo Nacional de Ciencias Naturales, Consejo Superior de Investigaciones Científicas, 486p.

Dumont, H.J. \& S.V. Negrea. 2002. Introduction to the Class Branchiopoda. Leiden, Backhuys Publishers, 398p.

Dumont, H.J. \& M. Silva-Briano. 1997. Sensory and glandular equipment of the trunk limbs of the Chydoridae and Macrothricidae. Hydrobiologia, Dordrecht, 360: 33-46.

Dumont, H.J. \& M. Silva-Briano. 1998. A reclassification of the Anomopoda families Macrothricidae and Chydoridae, with the creation of a new suborder, the Radopoda (Crustacea, Branchiopoda). Hydrobiologia, Dordrecht, 384: 119-149.

FrYer, G. 1974. Evolution and adaptative radiation in the Macrothricidae (Crustacea: Cladocera): a study in comparative functional morphology and ecology. Philosophical Transactions of the Royal Society of London (B), London, 269: 137-274.
FrYer, G. 1995. Phylogeny and adaptative radiation within the Anomopoda: A preliminary exploration. Hydrobiologia, Dordrecht, 307: 57-68.

Fryer, G. \& J.C. Paggi. 1972. A new cladoceran genus of the family Macrothricidae from Argentina. Crustaceana, Leiden, 23 (3): 255-262

Maddison, W.P. \& D.R. MAdDISON. 1992. MacClade: Analysis of phylogeny and character evolution, Version 3.04. Sunderland, Sinauer.

Olesen, J. 1998. A phylogenetic analysis of the Conchostraca and Cladocera (Crustacea, Branchiopoda, Diplostraca). Zoological Journal of the Linnean Society, London, 122: 491-536.

Olesen, J. 2000. An updated phylogeny of the ConchostracaCladocera clade (Branchiopoda, Diplostraca). Crustaceana, Leiden, 73: 869-886.

PAGgI, J.C. 1976. Cladoceros Macrothricidae nuevos para la fauna Argentina. Physis, Buenos Aires, 35 (91): 103-112.

Petкovski, T.K. 1973. Zur Cladoceren-Fauna Australiens. II. Sididae und Macrothricidae. Acta Musei Macedonici Scientiarum Naturalium, Skopje, 13 (8): 161-192.

Silva-Briano, M. \& H.J. Dumont. 2001. Wlassicsia, Bunops \& Onchobunops (Anomopoda), three related genera. Hydrobiologia, Dordrecht, 442: 1-28.

Smirnov, N.N. 1992. The Macrothricidae of the world. Amsterdam, SPB Academic Publishing, 143p.

Swofford, D.L. 1999. PAUP: Phylogenetic Analysis Using Parsimony and other methods, Version 4. Sunderland, Sinauer.

Received in 18.I.2005; accepted in 19.VIII.2005. 